\title{
Study on the Technological Pedagogical and Content Knowledge of Teacher Candidates and Their Learning Strategies
}

\author{
Niyazi GÜNDOĞMUŞ* \\ Institute of Education Sciences, Necmettin Erbakan University,
}

\section{Şemseddin GÜNDÜZ}

Department of Computer Education and Instructional Technology, Ahmet Keleşoglu Faculty of Education, Necmettin Erbakan University

Article history

Received:

19.02.2015

Received in revised form: 26.05.2015

Accepted:

27.05.2015

Key words:

Technology integration, technological pedagogical and content knowledge, learning strategies, teacher training, teacher candidate.
The aim of this paper is to evaluate the Technological Pedagogical and Content Knowledge (TPACK) of teacher candidates, defining the learning strategies of same candidates and researching whether there is relationship between these changes, or not. The research was carried out upon 493 senior class teachers candidate who studied in Necmettin Erbakan University Ahmet Keleşoğlu Faculty of Education in 2011-2012 spring term. The data is acquired by using Technological Pedagogical Content Knowledge Scale and Motivated Strategies for Learning Questionnaire. The data which is acquired from the scales and the information belongs to participants are analyzed with the SPSS (Statistical Package for the Social Sciences) 19.0 packaged software. During the analysis of data, it was used independent-samples t-test, correlation and regression analysis. According to the findings which were obtained from the research, TPACK levels of teacher candidates are occasionally, male candidates' technology, pedagogy and technological content knowledge skills are higher than girls. In the research, it can't be seen that there isn't any significant difference between groups according to score type used for the placement at university in TPACK components, a significant relationship was found between TPACK and learning strategies such as recursion, learning from friend, help search strategies' elaboration, organizing, critical thinking, metacognitive self-regulation, time operation environment monitoring, additionally it was understood that organization and critical thinking strategies predicted the TPACK.

\footnotetext{
*Correspondence: niyazigun@gmail.com
} 


\section{Introduction}

While teacher is trained, the knowledge and the skills that the teachers should have, can be seen in different periods of history and in different quality. It was primarily focused on content knowledge (CK) that the teachers should have. By the mid-1980s, it's began to adopt the idea that it isn't enough to teach content and pedagogical knowledge separately. After that it was added pedagogical knowledge (PCK) on content knowledge (CK) which points out their profession knowledge (Shulman, 1986). Technological pedagogical and content knowledge (TPACK) framework was formed by the addition of technology knowledge (TK) on Shulman's (1986) pedagogical content knowledge (PCK) which means understanding of how to interact with education and technology would be more effective (Koehler \& Mishra, 2009).

Nowadays technology knowledge can be integrated into education processes. Teachers are clearly the most important actors for doing the integration of technological education. Therefore qualified teacher should use technology for improving the material in just the same way as they also use technology for planning and preparing the lesson. Moreover, teachers need to have advanced "Technological and Pedagogical Content Knowledge" level in order to raise technological literate individuals. It is necessary to identify and enhance "'Technological Pedagogical and Content Knowledge'" level of teachers and to determine the obstacles encountered for increasing these levels.

In this reason we start searching from teacher candidates. In fact, if the teacher candidates see appropriate instructional technologies and the integration in their respective fields of pedagogy they will like to use both technology and pedagogy, and this will help their education for being teacher. It is obvious that there will be many researches on this point. Besides, TPACK researches can be carried out with different research lines. In the subsequent researches, it can be included different variables in order to analyze the effect to teacher candidates (Sahin, 2011).

In this study which analyzes and gathers the data upon the Learning Strategies and TPACK theoretical framework, senior class teacher candidates' technological pedagogical and content knowledge is evaluated according to their gender, and their learning strategies are determined, so we try to find the answers for these questions by analyzing the relation between these variables.

How is TPACK levels of teacher candidates?

Are there any differences of TPACK levels of teacher candidates according to their gender and score type used for the placement at university?

What are the learning strategies of teacher candidates' preferred?

Are there any differences in learning strategies of teacher candidates according to their gender and score type used for the placement at university?

What is the relationship between technological pedagogical and content knowledge with learning strategies for teacher candidates? 


\section{Method}

In this study, it was researched if there is relation between some variables on TPACK and Learning Strategies of teacher candidates. This research is a survey method because of having described the substantial situation of a group (Büyüköztürk, Çakmak, Akgün, Karadeniz, \& Demirel, 2008).

\section{Working Group}

Table 1 shows that the distribution of teacher candidates by their gender who participated the research.

Table 1. The Distribution of the Participants by Gender

\begin{tabular}{lll}
\hline Gender & Frequency $(f)$ & Percentage $(\%)$ \\
\hline Female & 326 & 66.1 \\
Male & 167 & 33.9 \\
Total & 493 & 100 \\
\hline
\end{tabular}

From 4th grade students of the faculty of education, totally 493 people participated on our research. One third of participants are male, two out of three are females. The distribution of score type used for the placement of teacher candidates at university is shown at Table 2.

Table 2. The distribution of participants by score type used for the placement at

\begin{tabular}{lll}
\hline Score Type & Frequency $(f)$ & Percentage $(\%)$ \\
\hline Verbal & 106 & 21.5 \\
Quantitative & 218 & 44.2 \\
Equally weighted & 169 & 34.3 \\
Total & 493 & 100 \\
\hline
\end{tabular}

\section{Data Collection Instrument}

The Technological Pedagogical and Content Knowledge (TPACK) Scale: Technological pedagogical and content knowledge is a five-point Likert scale which is consisting of totally 47 substances and seven sub-dimensions. Scale was developed by Sahin (2011), the validity and reliability of it has been proven. The answers of five point Likert scale are '1= I never know', '2= I know minimum level', '3= I know medium level', '4= I know well', and ' $5=\mathrm{I}$ know very well'. The scale consists of seven sub-dimensions. Respectively these dimensions are; technology knowledge (TK), pedagogical knowledge (PK), content knowledge (CK), technological pedagogical knowledge (TPK), pedagogical content knowledge (PCK) and technological pedagogical and content knowledge (TPACK).

The Learning Strategies Scale: It was developed in 1991 and validity, reliability of it has been proven by Pintrich, Smith, García, and McKeachie (1993). We used Turkish version of this scale which was customized by Altun and Erden (2006) because of working group. Scale was organized from 81 substances as seven-point Likert, it was used as cognitive and metacognitive strategies and resource management strategies which consists of 50 substances in 'Motivated Strategies for Learning Questionnaire'. The sub-dimensions are as follows. Recursion, elaboration, organizing, critical Thinking, metacognitive self-regulation, time and operation management, environment monitoring, regulation of effort, learning from friend, help search. 


\section{Data Analysis}

The data obtained from the scale and information about participants were analyzed by SPSS 19.0 (Statistical Package for the Social Sciences) package program. First we create score groups to evaluate the scores obtained from TPACK and Learning Strategies scale. TPACK ranking scores were divided into 5 groups is shown at table 3.

Table 3. Rating groups of TPACK score averages

\begin{tabular}{lccccc}
\hline & never & rarely & occasionally & often & always \\
\hline TK & $15-26.9$ & $27-38.9$ & $39-50.9$ & $51-62.9$ & $63-75$ \\
PK & $7-12.9$ & $13-17.9$ & $18-23.9$ & $24-28.9$ & $29-36$ \\
CK & $6-10.9$ & $11-15.9$ & $16-20.9$ & $21-24.9$ & $25-30$ \\
TPK & $4-6.9$ & $7-9.9$ & $10-13.9$ & $14-16.9$ & $17-20$ \\
TCK & $4-6.9$ & $7-9.9$ & $10-13.9$ & $14-16.9$ & $17-20$ \\
PCK & $7-12.9$ & $13-17.9$ & $18-23.9$ & $24-28.9$ & $29-36$ \\
TPACK & $6-10.9$ & $11-15.9$ & $16-20.9$ & $21-24.9$ & $25-30$ \\
\hline
\end{tabular}

The Learning Strategies scale ranking were also divided into 5 groups is shown at table 4.

Table 4. Rating Groups of Learning Strategies Score Averages

\begin{tabular}{|c|c|c|c|c|c|}
\hline & never & rarely & occasionally & often & always \\
\hline Recursion & $4-8.8$ & $8.9-13.6$ & $13.7-18.4$ & $18.5-23.2$ & $23.3-24$ \\
\hline Elaboration & $6-14.4$ & $14.5-22.8$ & $22.9-31.2$ & $31.3-39.6$ & $39.7-48$ \\
\hline Organizing & $4-8.8$ & $8.9-13.6$ & $13.7-18.4$ & $18.5-23.2$ & 23.3-24 \\
\hline Critical Thinking & $5-10.9$ & $11-15.9$ & $17-22.9$ & $23-28.9$ & $29-35$ \\
\hline $\begin{array}{l}\text { Metacognitive } \\
\text { self-regulation }\end{array}$ & $12-26.3$ & $26.4-40.7$ & $40.8-55.1$ & $55.2-69.5$ & $69.6-84$ \\
\hline $\begin{array}{l}\text { Time Operation } \\
\text { Environment Monitoring }\end{array}$ & $8-17.5$ & $17.6-27.1$ & $27.2-36.7$ & $36.8-46.4$ & $46.5-56$ \\
\hline Regulation of Effort & $4-8.8$ & $8.9-13.6$ & $13.7-8.4$ & $18.5-23.2$ & $23.3-24$ \\
\hline Learning from Friend & $3-6.5$ & $6.6-10.1$ & $10.2-13.7$ & $13.8-17.3$ & $17.4-21$ \\
\hline Help Search & $4-8.8$ & $8.9-13.6$ & $13.7-18.4$ & $18.5-23.2$ & $23.3-24$ \\
\hline
\end{tabular}

After that T-Test were analyzed to find any significant difference in sub-dimensions of scales among male and female prospective teachers. Analysis of variance (one way anova) were explained to determine whether differences in TPACK and Learning Strategies' scores of teacher candidates according to the score type used for the placement at university. Correlation values were calculated to understand relationship between TPACK and Learning Strategies of teacher candidates and regression analyzed to find the learning strategies that predicting the TPACK scores of teacher candidates. In this search the level of significance was adopted as $\mathrm{p}=.05$.

\section{Findings}

TPACK and its sub-dimensions score for the evaluation of teacher candidate is shown in Table 5. 
Table 5. TPACK level of teacher candidates

\begin{tabular}{lllcc}
\hline & $\bar{X}$ & $S$ & Minimum & Maximum \\
\hline TK & 51.46 & 11.222 & 15 & 75 \\
PK & 20.54 & 4.566 & 8 & 30 \\
CK & 20.67 & 4.158 & 10 & 30 \\
TPK & 14.15 & 3.083 & 6 & 20 \\
TPK & 13.75 & 3.036 & 5 & 20 \\
PCK & 25.22 & 4.720 & 10 & 35 \\
TPACK & 17.42 & 3.876 & 5 & 25 \\
\hline
\end{tabular}

When table 5 is analyzed, at the sub-dimension of TPACK scale we can't be seen that there is no "never" and "rarely" level according to table 3. Pedagogical knowledge (PK), content knowledge (CK), technological content knowledge (TCK), technological pedagogical and content knowledge (TPACK) levels are "occasionally"; technological knowledge (TK), technological pedagogical knowledge (TPK), pedagogical content knowledge (PCK) levels are "often" according to table 3.

The scores of teacher candidates from TPACK scale that the distribution by gender is shown at Table 6.

Table 6. A comparison of TPACK components in reference to gender

\begin{tabular}{cllcccc}
\hline & Gender & $N$ & $\bar{X}$ & $S$ & $t$ & $p$ \\
\hline \multirow{2}{*}{ TK } & Female & 326 & 49.55 & 10.345 & -5.432 & $0.000^{*}$ \\
& Male & 167 & 55.19 & 11.940 & & \\
PK & Female & 326 & 20.22 & 4.465 & -2.146 & $0.032^{*}$ \\
& Male & 167 & 21.15 & 4.709 & & \\
& Female & 326 & 20.45 & 4.027 & -1.686 & 0.092 \\
& Male & 167 & 21.11 & 4.382 & & \\
TPK & Female & 326 & 13.95 & 2.969 & & $0.043^{*}$ \\
& Male & 167 & 14.54 & 3.267 & -2.031 & \\
TCK & Female & 326 & 13.47 & 2.928 & & $0.003^{*}$ \\
& Male & 167 & 14.32 & 3.170 & -2.969 & \\
PCK & Female & 326 & 24.98 & 4.728 & & 0.120 \\
& Male & 167 & 25.68 & 4.684 & -1.557 & \\
TPACK & Female & 326 & 17.21 & 3.677 & & 0.080 \\
& Male & 167 & 17.85 & 4.215 & -1.752 & \\
\hline
\end{tabular}

$*: p<.05$

It can be understood from Table 6, it was found significant difference in sub-dimensions among male and female teacher candidates; Technological knowledge $(\mathrm{t}=-5.432)$, pedagogical knowledge $(\mathrm{t}=-2.146)$, technological pedagogy knowledge $(\mathrm{t}=2.712)$, technological content knowledge $(\mathrm{t}=-2.969)$. From the group average and standard deviations, in sub-dimensions of technological knowledge, pedagogical knowledge, technological pedagogy knowledge and technological content knowledge, there is statistically significant difference between male and female teacher candidates which is in favor of male teacher candidates. The knowledge level of male teacher candidates on these four components is higher when compared with female teacher candidates. There isn't any statistically significant 
difference between male and female teacher candidates on the other three knowledge level.

Table 7. The one way analysis of variance (Anova) results according to score type used for the placement at university

\begin{tabular}{|c|c|c|c|c|c|c|}
\hline & & Sum of Squares & $\begin{array}{l}\text { Degree of } \\
\text { freedom }\end{array}$ & Mean Square & $F$ & $p$ \\
\hline \multirow{3}{*}{ TK } & $\begin{array}{l}\text { Between } \\
\text { Groups }\end{array}$ & 1388.14 & 2 & 694.072 & \multirow{3}{*}{5.615} & \multirow{3}{*}{$0.004^{*}$} \\
\hline & $\begin{array}{l}\text { Within } \\
\text { Groups }\end{array}$ & 60568.41 & 490 & 123.609 & & \\
\hline & Total & 61956.56 & 492 & & & \\
\hline \multirow{3}{*}{ PK } & $\begin{array}{l}\text { Between } \\
\text { Groups }\end{array}$ & 48.19 & 2 & 24.093 & \multirow{3}{*}{1.156} & \multirow{3}{*}{0.315} \\
\hline & $\begin{array}{l}\text { Within } \\
\text { Groups }\end{array}$ & 10208.44 & 490 & 20.834 & & \\
\hline & Total & 10256.63 & 492 & & & \\
\hline \multirow{3}{*}{ CK } & $\begin{array}{l}\text { Between } \\
\text { Groups }\end{array}$ & 65.93 & 2 & 32.964 & \multirow{3}{*}{1.914} & \multirow{3}{*}{0.149} \\
\hline & $\begin{array}{l}\text { Within } \\
\text { Groups }\end{array}$ & 8440.49 & 490 & 17.225 & & \\
\hline & Total & 8506.42 & 492 & & & \\
\hline \multirow{3}{*}{ TPK } & $\begin{array}{l}\text { Between } \\
\text { Groups }\end{array}$ & 13.85 & 2 & 6.926 & \multirow{3}{*}{0.728} & \multirow{3}{*}{0.483} \\
\hline & $\begin{array}{l}\text { Within } \\
\text { Groups }\end{array}$ & 4661.74 & 490 & 9.514 & & \\
\hline & Total & 4675.59 & 492 & & & \\
\hline \multirow{3}{*}{ TCK } & $\begin{array}{l}\text { Between } \\
\text { Groups }\end{array}$ & 36.19 & 2 & 18.094 & \multirow{3}{*}{1.971} & \multirow{3}{*}{0.140} \\
\hline & $\begin{array}{l}\text { Within } \\
\text { Groups }\end{array}$ & 4499.11 & 490 & 9.182 & & \\
\hline & Total & 4535.30 & 492 & & & \\
\hline \multirow{3}{*}{ PCK } & $\begin{array}{l}\text { Between } \\
\text { Groups }\end{array}$ & 27.30 & 2 & 13.648 & \multirow{3}{*}{0.612} & \multirow{3}{*}{0.543} \\
\hline & $\begin{array}{l}\text { Within } \\
\text { Groups }\end{array}$ & 10933.91 & 490 & 22.314 & & \\
\hline & Total & 10961.21 & 492 & & & \\
\hline \multirow{3}{*}{ TPACK } & $\begin{array}{l}\text { Between } \\
\text { Groups }\end{array}$ & 2.44 & 2 & 1.218 & \multirow{3}{*}{0.081} & \multirow{3}{*}{0.922} \\
\hline & $\begin{array}{l}\text { Within } \\
\text { Groups }\end{array}$ & 7387.96 & 490 & 15.077 & & \\
\hline & Total & 7390.40 & 492 & & & \\
\hline
\end{tabular}

Analysis of variance (one way anova) results were shown in table 7 to determine whether differences in TPACK and Learning Strategies' scores of teacher candidates according to the score type used for the placement at university. When table 7 is analyzed, except technological knowledge (TK), it can't be seen that there isn't any significant difference between groups according to score type used for the placement at university in TPACK components. The significant difference level is $\mathrm{p}<.05$ at technological knowledge (TC) of tacher candidates. To understand which score type is better at technological knowledge that the results of the scheffe test are shown at Table 8. 
Table 8.The scheffe test results according to score type used for the placement at university

\begin{tabular}{|c|c|c|c|c|c|}
\hline & Score type & \multicolumn{2}{|c|}{ Mean difference } & \multirow{3}{*}{$\begin{array}{c}\text { Standard error } \\
1.316 \\
\mathbf{1 . 3 7 8}\end{array}$} & \multirow{3}{*}{\begin{tabular}{l}
\multicolumn{1}{c}{$p$} \\
0.136 \\
$\mathbf{0 . 0 0 4} *$
\end{tabular}} \\
\hline \multirow{3}{*}{$\mathrm{TC}$} & \multirow{2}{*}{ Verbal } & Equally weighted & -2.636 & & \\
\hline & & Quantitative & $-4.608^{*}$ & & \\
\hline & Equally weighted & Quantitative & -1.972 & 1.139 & 0.225 \\
\hline \multirow{3}{*}{$\mathrm{PC}$} & \multirow{2}{*}{ Verbal } & Equally weighted & -0.388 & 0.540 & 0.773 \\
\hline & & Quantitative & -0.842 & 0.566 & 0.331 \\
\hline & Equally weighted & Quantitative & -0.454 & 0.468 & 0.625 \\
\hline \multirow{3}{*}{ CK } & \multirow{2}{*}{ Verbal } & Equally weighted & -0.128 & 0.491 & 0.967 \\
\hline & & Quantitative & 0.677 & 0.514 & 0.421 \\
\hline & Equally weighted & Quantitative & 0.805 & 0.425 & 0.168 \\
\hline \multirow{3}{*}{ ТPC } & \multirow{2}{*}{ Verbal } & Equally weighted & -0.259 & 0.365 & 0.777 \\
\hline & & Quantitative & 0.111 & 0.382 & 0.959 \\
\hline & Equally weighted & Quantitative & 0.370 & 0.316 & 0.504 \\
\hline \multirow{3}{*}{ TCK } & \multirow{2}{*}{ Verbal } & Equally weighted & -0.707 & 0.359 & 0.144 \\
\hline & & Quantitative & -0.408 & 0.375 & 0.554 \\
\hline & Equally weighted & Quantitative & 0.299 & 0.311 & 0.629 \\
\hline \multirow{3}{*}{ PCK } & \multirow{2}{*}{ Verbal } & Equally weighted & -0.591 & 0.559 & 0.573 \\
\hline & & Quantitative & -0.250 & 0.585 & 0.913 \\
\hline & Equally weighted & Quantitative & 0.340 & 0.484 & 0.781 \\
\hline \multirow{3}{*}{ TPACK } & \multirow{2}{*}{ Verbal } & Equally weighted & 0.020 & 0.460 & 0.999 \\
\hline & & Quantitative & -0.134 & 0.481 & 0.962 \\
\hline & Equally weighted & Quantitative & -0.154 & 0.398 & 0.928 \\
\hline
\end{tabular}

$*: \mathrm{p}<.05$

When table 8 is analyzed, there is a significant difference in terms of technology knowledge $(p<.05)$ among verbal and quantitative score type in favor of quantitative teacher candidates.

Learning strategies' score mean, standard deviation, the lowest and highest values for the evaluation of teacher candidate is shown in Table 9.

Table 9. The learning strategies' level of teacher candidates

\begin{tabular}{lcccc}
\hline & $\bar{X}$ & $S$ & Minimum & Maximum \\
\hline Recursion & 14.17 & 3.430 & 4 & 21 \\
Elaboration & 30.34 & 6.171 & 11 & 42 \\
Organizing & 20.19 & 4.434 & 5 & 28 \\
Critical thinking & 23.44 & 5.083 & 8 & 35 \\
Metacognitive self-regulation & 56.57 & 9.785 & 24 & 82 \\
Time operation environment & 36.25 & 6.346 & 15 & 56 \\
Regulation of effort & 16.74 & 3.815 & 4 & 28 \\
Learning from friend & 12.28 & 3.940 & 3 & 21 \\
Help search & 18.20 & 4.176 & 6 & 28 \\
\hline
\end{tabular}

When table 9 is analyzed it can be seen that recursion, time operation environment, learning from friend, help search strategies of teacher candidates are "occasionally"; elaboration, organizing, critical thinking and metacognitive self-regulation strategies are "often" according 
to table 4. The distribution of teacher candidates for learning strategies according to their gender is given in Table 10:

Table 10. Comparison of learning strategies in reference to gender

\begin{tabular}{llllccc}
\hline & Gender & $N$ & $\bar{X}$ & $S$ & $t$ & $p$ \\
\hline \multirow{2}{*}{ Recursion } & Female & 326 & 14.39 & 3.377 & \multirow{2}{*}{1.923} & 0.055 \\
& Male & 167 & 13.76 & 3.506 & & \\
& Female & 326 & 30.79 & 5.992 & \multirow{2}{*}{2.270} & $0.024^{*}$ \\
& Male & 167 & 29.47 & 6.433 & & \\
Organizing & Female & 326 & 20.60 & 4.409 & \multirow{2}{*}{2.872} & $0.004^{*}$ \\
& Male & 167 & 19.40 & 4.389 & & \\
Critical Thinking & Female & 326 & 23.28 & 5.063 & & \multirow{2}{*}{0.311} \\
Metacognitive & Male & 167 & 23.77 & 5.121 & & \\
self-regulation & Male & 167 & 56.22 & 10.352 & 0.559 & 0.576 \\
Time Operation & Female & 326 & 36.40 & 6.044 & & \\
Environment & Male & 167 & 35.96 & 6.908 & 0.734 & 0.463 \\
Monitoring & Female & 326 & 16.64 & 3.889 & & \\
Regulation of & Male & 167 & 16.93 & 3.671 & -0.790 & 0.430 \\
Effort & Female & 326 & 12.12 & 4.029 & & \\
Learning from & Male & 167 & 12.59 & 3.753 & -1.271 & 0.204 \\
Friend & Female & 326 & 18.23 & 4.273 & \multirow{2}{*}{0.187} & \multirow{2}{*}{0.852} \\
Help Search & Male & 167 & 18.16 & 3.992 & & \\
\hline
\end{tabular}

$*: p<.05$

When Table 10 is analyzed, it can be seen that there isn't any significant difference by their gender on the learning strategies such as recursion, elaboration, organizing, critical thinking, metacognitive self-regulation, time and operation management, environment monitoring, regulation of effort, learning from friend and help search that the teacher candidates used. But

When we look at elaboration extent the average score of female participants are 30.79 , and standard deviation is 5.99 while the average point of male participants 29.47 and standard deviation is 6.43. It was made a t test to understand if there is significant difference between male and female teacher candidates on using learning strategies. As a result of the test, a significant difference was found on using elaboration strategies between male and female teacher candidates $(\mathrm{t}=2.27 ; \mathrm{p}<.05)$. It can be said that female teacher candidates are using elaboration learning strategies more frequently than male teacher candidates.

When we look at organizing dimension, the average point of female participants is 20.60; standard deviation is 4.41 , meanwhile the average point of male participants is 1.40 and standard deviation is 4.39. It was found a significant difference between male and female teacher candidates on using organizing strategies $(t=2.87 ; \mathrm{p}<.05)$. It can be mentioned that female teacher candidates are using organizing learning strategies more often. 
Table 11. Correlation Values between TPACK and Learning Strategies

\begin{tabular}{lc}
\hline Learning Strategies & $T P A C K$ \\
\hline Recursion & $0.247^{* *}$ \\
Elaboration & $0.392^{* *}$ \\
Organizing & $0.379^{* *}$ \\
Critical Thinking & $0.378^{* *}$ \\
Metacognitive self-regulation & $0.405^{* *}$ \\
Time ,Operation Environment Monitoring & $0.333^{* *}$ \\
Regulation of Effort & 0.067 \\
Learning from Friend & $0.226^{* *}$ \\
Help Search & $0.249^{* *}$ \\
\hline
\end{tabular}

$* *: p<.01$

The relation between TPACK and learning strategies is analyzed. The Pearson correlation coefficients are given at Table 11. When the correlation coefficients are analyzed, it can be seen that except regulation of effort, there are correlations between learning strategies and TPACK of teacher candidates such as recursion, learning from friend and help search strategies' correlation coefficients are at little level and elaboration, organizing, critical thinking, metacognitive self-regulation, time operation environment monitoring strategies' correlation coefficients are "middle" level. İf we want to learn which learning strategies predict the TPACK. The results of the regression analysis are shown at Table 12 in order to find the learning strategies that predicting the TPACK scores of teacher candidates.

Table 12. The Results of Regression Analysis on Predicting TPACK Scores According to Learning Strategies of Teacher candidates

\begin{tabular}{|c|c|c|c|c|c|}
\hline \multirow{2}{*}{$\begin{array}{l}\text { Independent } \\
\text { Variables }\end{array}$} & \multicolumn{2}{|c|}{ Standard Points } & \multirow{2}{*}{$\begin{array}{c}\text { tandardized } \\
\text { Points } \\
\text { Beta } \\
\end{array}$} & \multirow[b]{2}{*}{$t$} & \multirow[b]{2}{*}{$p$} \\
\hline & $B$ & SH & & & \\
\hline Invariant & 97.454 & 7.785 & & 12.518 & 0.000 \\
\hline Recursion & -0.252 & 0.401 & -0.031 & -0.629 & 0.530 \\
\hline Elaboration & 0.095 & 0.339 & 0.021 & 0.281 & 0.779 \\
\hline Organizing & 1.253 & 0.395 & 0.201 & 3.171 & $0.002 *$ \\
\hline Critical Thinking & 0.863 & 0.385 & 0.158 & 2.240 & $0.026^{*}$ \\
\hline $\begin{array}{l}\text { Metacognitive self- } \\
\text { regulation }\end{array}$ & 0.268 & 0.222 & 0.095 & 1.205 & 0.229 \\
\hline $\begin{array}{l}\text { Time, Operation } \\
\text { Environment } \\
\text { Monitoring }\end{array}$ & 0.208 & 0.238 & 0.048 & 0.876 & 0.381 \\
\hline Regulation of Effort & -0.517 & 0.340 & -0.071 & -1.520 & 0.129 \\
\hline Learning from Friend & 0.275 & 0.355 & 0.039 & 0.776 & 0.438 \\
\hline Help Search & 0.193 & 0.357 & 0.029 & 0.540 & 0.589 \\
\hline
\end{tabular}


When Table 12 is analyzed, using only organizing and critical thinking strategies can explain the \%21 percentage of TPACK. When examining the parameters of the regression model, according to standardized regression coefficient (Beta), it can be seen that predictor variables have the relative order of importance on TPACK; organizing, critical thinking, metacognitive self-regulation, time operation and environment monitoring, learning from friend, help search, elaboration, recursion and regulation of organizing effort. It was understood that organizing $(\mathrm{t}=3.171 ; \mathrm{p}<.05)$ and critical thinking $(\mathrm{t}=2.240 ; \mathrm{p}=<.05)$ from independent variables, are one of the important predictor. As a result of the regression analysis, there wasn't any predictor characteristic of recursion and regulation of organizing effort.

\section{Discussion}

Teacher candidates are mostly using metacognition, managing the cognition and affective strategies. Female participants are using elaboration and organizing strategies more often. The use of learning strategies - recursion, critical thinking, metacognitive selfregulation, time and operation management, environment monitoring, regulation of effort, learning from friend and help search are very close between male and female participants. The knowledge level of male teacher candidates on technological knowledge, pedagogical knowledge, technological pedagogic knowledge and technological content knowledge from TPACK, is higher than female teacher candidates.

There is middle level of relation between the learning strategies which teacher candidates use (organizing, critical thinking, metacognitive self-regulation, time operation environment monitoring strategies' correlation coefficients) and the technological pedagogic content knowledge level. Organizing and critical thinking strategies can explain the $\% 21$ percentage of TPACK levels of teacher candidates.

As a result of this research, teacher candidates use learning strategies as intense. These findings in our research are similar to research in order to determine the learning strategies that teacher candidates use when working by Yüksel and Koşar (2001).

Öztürk (1995) examined the case of learning strategies used by university students and find that university students were using the most metacognitive self-regulation strategies and the least recursion strategy similar to our study.

When we look at the survey by Karakış and Çelenk (2007) to determine the level of use of students' learning strategies studying in different faculties can be seen that metacognitive selfregulation strategies were used often by students.

In the research by Altun (2005) using with the same scale find that the score means of metacognitive self-regulation, time operation environment monitoring, regulation of effort, help research strategies were 49.4, 35.4, 18.6, 18.5 and close to this study score means which are 56.57, 36.25, 16.7, 18.2. When Altun (2005) study is analyzed female participants' regulation of effort strategies and male participant's metacognitive self-regulation, time operation environment monitoring strategies are predicting their success. Female's strategies of elaboration and organizing are significantly different from male participants just like our research findings.

In the study by Şahin and Çakar (2011) with the $2404^{\text {th }}$ grade students from faculty of 
education participated was found that significant difference in terms of recursion, elaboration, organizing, metacognitive self-regulation strategies in favor of female participants. In our research significant difference was found at only elaboration and organizing strategies between male and females.

When we look at the survey with 291 third and fourth grade teacher candidates by Nurten, Sağırlı, İhsan, and Kaşkaya (2009) using with the same scale find that significant difference in terms of elaboration, organizing strategies in favor of female participants. This findings are similar to our research.

At the study by Saban and Tümkaya (2008) with $2304^{\text {th }}$ grade student from primary teaching we can be seen that significant difference at learning strategies' sub-dimensions in favor of female participants. These strategies help search, metacognitive self-regulation, time operation environment monitoring. If we look our findings we will also see significant difference at learning strategies' sub-dimensions in favor of female participants.

If we look at other findings of this research we will see significant difference at time operation environment monitoring, regulation of effort strategies according to score type used for the placement at university but we can't see any differences at other sub-dimension of learning strategies. At the study by Karakış and Çelenk (2007) with the students from different faculties there isn't any significant difference at learning strategies in terms of faculties.

If we discuss about TPACK, Timur and Taşar (2011) were found in their research that technology knowledge (TC) of teacher candidates has advanced but not enough to integrate the technology into pedagogical knowledge because of lack of experience.

In the research by Canbolat (2011) with $1434^{\text {th }}$ grade students from the department of mathematics teachers faculty of education and using with the same scale find that the score means of TPACK (TC, PK, CK, PCK, TPK,TCK TPACK) were 46.34, 19.09, 20.48, 23.81, $13.01,11.84,15.83$ and except technology knowledge close to this study score means of TPACK (TK, PK, CK, PCK, TPK,TCK TPACK) which were 51.46, 20.54, 20.67, 25.22, $14.15,13.75$ and 17.42. In that study there is statistically significant difference at TK, TPK, TCK and TPACK in favor of male participants similar to our study that we have found significant difference at TK, TPK, and TCK.

It was understood that the participants whose TPACK level are generally occasionally, they use learning strategies often at least. It can also be provided training for male participants to use their learning strategies more efficiently. It can be done researches about the reasons why female participants are using organizing and elaboration strategies more frequent than male participants. Organizing and critical thinking strategies predicting the TPACK. It should be taken proper steps to improve their technological knowledge. It should be carried out works or studies in order to improve the TPACK levels of teacher candidates. Similar researches should be carried out for teachers as well.

\section{Acknowledgement}

It is made from the first author's master's thesis named 'Analysis Of Relationship Between Technological Pedagogical and Content Knowledge And Learning Strategies Of Teacher Candidates'. 


\section{References}

Altun, S. (2005). Öğrencilerin öz düzenlemeye dayalı öğrenme stratejilerinin ve öz yeterlik algılarının öğrenme stilleri ve cinsiyete göre matematik başarısını yordama gücü. Yayımlanmamış Doktora Tezi, Yıldız Teknik Üniversitesi, Sosyal Bilimler Enstitüsü, İstanbul.

Altun, S., \& Erden, M. (2006). Öğrenmede motive edici stratejiler ölçeğinin geçerlik ve güvenirlik çalışması. Yeditepe Üniversitesi. Edu7, 2(1), 1-16.

Büyüköztürk, S., Çakmak, E. K., Akgün, Ö., Karadeniz, S., \& Demirel, F. (2008). Bilimsel arastirma yöntemleri. Ankara: Pegem Akademi Yayincilik.

Canbolat, N. (2011). Matematik Öğretmen Adaylarının Teknolojik Pedagojik Alan Bilgileri ile Düşünme Stilleri Arasındaki İlişkinin İncelenmesi. Yüksek Lisans Tezi, Selçuk Üniversitesi Ë̆itim Bilimler Enstitüsü, Konya.

Karakış, Ö., \& Çelenk, S. (2007). Farklı Fakültelerde Öğrenim Gören Öğrencilerin Genel Öğrenme Stratejilerini Kullanma Düzeyleri" AİB Ü Örneği". Abant İzzet Baysal Üniversitesi Ĕ̈itim Fakültesi Dergisi.

Koehler, M., \& Mishra, P. (2009). What is technological pedagogical content knowledge (TPACK)? Contemporary Issues in Technology and Teacher Education, 9(1), 60-70.

Nurten, E., Sağırlı, M. Ö., İhsan, Ü., \& Kaşkaya, A. (2009). The Examination Of Learning Strategies According To Different Variables. Journal of Education Faculty, 11(2), 227-238.

Öztürk, B. (1995). Genel öğrenme stratejilerinin öğrenciler tarafından kullanılma durumları. Yayımlanmamış Doktora Tezi. Ankara: Gazi Üniversitesi Sosyal Bilimler Enstitüsü.

Pintrich, P. R., Smith, D. A., García, T., \& McKeachie, W. J. (1993). Reliability and predictive validity of the Motivated Strategies for Learning Questionnaire (MSLQ). Educational and psychological measurement, 53(3), 801-813.

Saban, A. İ., \& Tümkaya, S. (2008). Öğretmen adaylarının öğrenme stratejileri ile sosyo demografik özellikler ve akademik başarıları arasındaki ilişkinin incelenmesi. Ege Eğitim Dergisi, 9(1).

Sahin, I. (2011). Development of survey of technological pedagogical and content knowledge (TPACK). Turkish Online Journal of Educational Technology-TOJET, 10(1), 97-105.

Shulman, L. S. (1986). Those who understand: Knowledge growth in teaching. Educational researcher, 4-14.

Şahin, H., \& Çakar, E. (2011). Eğitim Fakültesi Öğrencilerinin Öğrenme Stratejilerini ve Akademik Güdülenme Düzeylerinin Akademik Başarılarına Etkisi. Türk Eğitim Bilimleri Dergisi, 9(3).

Timur, B., \& Taşar, M. F. (2011). Teknolojik pedagojik alan bilgisi öz güven ölçeğinin (TPABÖGÖ) Türkçe'ye uyarlanması. Gaziantep University-Journal of Social Sciences, 10(2), 867-890.

Yüksel, S., \& Koşar, E. (2001). Eğitim fakültesi öğrencilerinin ders çalışırken kullandıkları öğrenme stratejileri. Çağdaş Ĕ̆itim Dergisi, 278, 29-36. 